\title{
Comparative analysis of male germ cell proliferation and apoptosis in wild and captive Atlantic bluefin tuna (Thunnus thynnus L.)
}

\author{
R. Zupa ${ }^{1}$, C. Fauvel ${ }^{2}$, C. C. Mylonas ${ }^{3}$, N. Santamaria ${ }^{1}$, L. Valentini ${ }^{1}$, C. Pousis ${ }^{1}$, M. Papadaki ${ }^{3}$, \\ M. Suquet ${ }^{2}$, F. de la Gándara ${ }^{4}, G$. Bello ${ }^{1}$, G. De Metrio ${ }^{1}$, A. Corriero ${ }^{1,}$
}

\footnotetext{
${ }^{1}$ Department of Animal Production, University of Bari Aldo Moro, Valenzano (BA), Italy

2 UMR 5119 ECOSYM, UM2-UM1-CNRS-IRD-IFREMER, Palavas, France

${ }^{3}$ Institute of Aquaculture, Hellenic Center for Marine Research, Crete, Greece

${ }^{4}$ Centro Oceanográfico de Murcia, Instituto Español de Oceanografía, Puerto de Mazarrón (Murcia), Spain

*: Corresponding author : A. Corriero, email address : a.corriero@veterinaria.uniba.it
}

\begin{abstract}
:
The most commonly observed reproductive dysfunction in male fishes reared in captivity is reduction in sperm volume and quality. The Atlantic bluefin tuna Thunnus thynnus (Osteichthyes: Scombridae) is one of the few large pelagic and migratory marine fishes maintained in captivity with the purpose of establishing breeding populations to support an aquaculture industry. The objectives of the present study were to compare male germ cell proliferation and apoptosis between wild and captive individuals at two different phases of the spermatogenetic cycle, and to evaluate sperm motility characteristics of captive individuals. Histological observations were performed to analyze testicular activity, and germ cell proliferation and apoptosis were evaluated through the immunohistochemical detection of proliferating cell nuclear antigen (PCNA) and the terminal deoxynucleotidyl transferasemediated d'UTP nick end labeling (TUNEL) method, respectively. Computer-assisted sperm analysis (CASA) was used to evaluate sperm motility. Results showed that germ cell proliferation was delayed and germ cell apoptosis increased in captive animals relative to wild individuals. Sperm motility of samples obtained from captive individuals was anomalous, both in terms of motility duration and swimming efficiency. Thus it appears that rearing in captivity impairs male reproductive function through, at least, changes in germ cell proliferation and apoptosis.
\end{abstract}




\section{Introduction}

The Atlantic bluefin tuna Thunnus thynnus (Linnaeus, 1758) is one of the most economically important fishery species and is subject to an intense fishing pressure in the Atlantic Ocean and the Mediterranean Sea (Mylonas et al., 2010). Both management units recognized by the International Commission for the Conservation of Atlantic Tunas (ICCAT), the western Atlantic unit (western stock) and the eastern Atlantic and Mediterranean unit (eastern stock), are considered overexploited, since the adult population (spawning stock biomass) has been reduced dramatically during the last 4 decades (Anonymous, 2006a). More than $80 \%$ of the fish caught in the Mediterranean Sea are transferred alive into floating cages and fattened for a few months before being slaughtered and sold to the Japanese market (Mylonas et al., 2010). The conversion of this capture-based activity to a self-sustained aquaculture industry requires the establishment of captive broodstocks capable of reproducing successfully (Mylonas et al., 2007).

Many fishes reared in captivity often exhibit reproductive problems caused by endocrine dysfunctions (Zohar and Mylonas, 2001; Mylonas and Zohar, 2007, 2008; Mylonas et al., 2010). In males, the most common problem is the reduced production of sperm and/or the reduced quality of the produced sperm. These dysfunctions have been attributed to an insufficient pituitary stimulation by hypothalamic gonadotropin-releasing hormone $(\mathrm{GnRH})$ and, as a consequence, to an inadequate luteinizing hormone ( $\mathrm{LH})$ release by pituitary gonadotropes (Zohar and Mylonas, 2001; Rosenfeld et al., 2012). In captive male Atlantic bluefin tuna the testes did not reach their full development and treatment with a $\mathrm{GnRH}$ agonist $(\mathrm{GnRHa})$ was not effective in inducing an evident testicular maturation (Corriero et al., 2007), though it stimulated spermatogonial proliferation and reduced the presence of apoptotic germ cells (Corriero et al., 2009). The fact that administration of exogenous hormones appeared to support spermatogenic function in captive individuals suggested that captivity may impair spermatogenesis in Atlantic bluefin tuna, at least in part by interfering with spermatogonial proliferation and inducing germ cell apoptosis.

Spermatogenesis is a complex process, involving the activation of the hypothalamuspituitary-gonad axis via secretion of $\mathrm{GnRH}$ and of the two pituitary gonadotropins, follicle stimulating hormone (FSH) and LH (Cheng et al., 2010). Throughout spermatogenesis, germ cell proliferation and apoptosis may play an important role in determining sperm output (Sharpe, 1994), modifying an incorrect germ cell:Sertoli cell ratio (Prisco et al., 2003), as well as in preventing the maturation of aberrant gametes (Blanco-Rodríguez and Martínez-García, 1996; Corriero et al., 2007). Apoptosis is a form of programmed cell death that depends on the balanced effects between "survival" and "death" factors (Young and Nelson, 2001). Germ cell "survival" factors include the pituitary gonadotropins and androgens (Young and Nelson, 2001) that stimulate germ cell proliferation (Schulz and Miura, 2002; Schulz et al., 2010) and whose withdrawal is responsible for germ cell apoptosis (Young and Nelson, 2001).

It is not yet clear whether, and to what extent, rearing conditions may be responsible for an impairment of spermatogenesis in Atlantic bluefin tuna, in terms of germ cell proliferation and apoptosis, as well as of sperm quality. Recent reviews showed large variations of sperm quality in captive fishes due to a variety of factors, including stress and rearing conditions (Rurangwa et al., 2004; Cabrita et al., 2009; Bobe and Labbé, 
2010) and adaptation of computer assisted sperm analysis (CASA) to the specificity of fish sperm in the last decade allowed a precise description of motility, a determinant aspect of sperm quality (Amann and Katz, 2004). The objectives of the present study were to (a) examine the spermatogenetic cycle of Atlantic bluefin tuna in captivity, (b) compare male germ cell proliferation and apoptosis between wild and captive individuals at two different phases of the spermatogenetic cycle, and (c) evaluate sperm motility characteristics from captive individuals.

\section{Materials and Methods}

\subsection{Sampling}

Testis samples were collected during 2008 from 30 adult specimens reared in cages at different sites in the Mediterranean Sea (Table 1). A total of 18 fish was sampled in Cartagena (South-eastern coast of Spain) in April $(n=6)$, May $(n=8)$ and July $(n=4)$. During June, 5 fish were sampled in Malta and 7 fish were sampled in Vibo Marina (South Tyrrhenian Sea, Italy). All captive fish were treated according to the "Council Directive 86/609 EEC for the protection of animals used for experimental and other scientific purposes" (EEC, 1986) and the "Ethical justification for the use and treatment of fishes in research" (Anonymous, 2006b). For comparison, 20 testis samples from adult wild fish (Table 1) were collected in May $(n=8)$ and in June $(n=6)$ from a tuna trap in the island of San Pietro (South-western of Sardinia, Italy), and in May in a tuna trap in Kenitra, Morocco $(n=6)$. Due to fact that the Atlantic bluefin tuna purse-seine fishery operates exclusively during the spawning period (May-June), when the brood fish aggregate and spend more time close to the water surface, it was not possible to collect samples from wild fish in April and July -- i.e., at the beginning and end of the reproductive season --, which would have optimized the comparison of the spermatogenetic process in wild and captive individuals. Therefore the study of germ cell proliferation and apoptosis was made on testis samples collected in May and June, which is the peak of the spermatogenic process.

For the evaluation of sperm motility characteristics, the five fish sampled in Malta during the spawning season were used (Table 1). Four individuals were releasing sperm upon administration of pressure on the abdomen, while the other male did not release any sperm, nevertheless when dissected the testes were found to contain sperm (intratesticular sperm). Neither any mating behavior nor any evidence of spawning were recorded in the Malta cages during this season.

Curved fork length $\left(C L_{F}\right.$, nearest $\left.\mathrm{cm}\right)$ and body mass $\left(M_{B}\right.$, nearest $\left.\mathrm{kg}\right)$ were recorded whenever possible prior to excision of the gonads (Table 1). Testes were dissected onboard a service vessel, placed on crushed ice and transported to a laboratory. From each fish, a $1-\mathrm{cm}$ thick cross section was taken from the middle third of the testes. The samples were fixed in Bouin"s solution (Sigma Aldrich) for about $4 \mathrm{~h}$ and processed for paraffin embedding as described below. Sperm was obtained by direct pressure on the dissected testes. The semen was collected with $2 \mathrm{ml}$ syringes and aliquots of $0.5 \mathrm{ml}$ were prepared and stored into $5-\mathrm{ml}$ test tubes maintained at $4^{\circ} \mathrm{C}$ until analysis. The time interval between fish death and sperm motility evaluations was between 1 and $2 \mathrm{~h}$. 


\subsection{Classification of germ cell types and detection of proliferating and apoptotic germ cells}

Testis samples from all the fish used in the present study (Table 1) were dehydrated in increasing ethanol concentrations, clarified in Histolemon (Carlo Erba Reagents, Rodano, Milan, Italy) and embedded in paraffin wax. Five- $\mu$ m thick sections were cut and stained with haematoxylin-eosin.

In Atlantic bluefin tuna testis, spermatogonia are distributed from the periphery to the sperm duct system, so that the testicular organization corresponds to that described as "unrestricted spermatogonial type" by Grier et al. (1980) and as "lobular type" by Billard (1986); in the present study we used the latter terminology. In Atlantic bluefin tuna (as in other fishes and amphibians), the testicular structure is cystic, i.e. each clone of germ cells, derived by a single spermatogonium, is enveloped by cytoplasmic extension of Sertoli cells (Abascal et al., 2004). The classification of the reproductive state of males was based on the type of germ cells localized in the seminiferous epithelium, as well as on the subjective evaluation of the abundance of spermatozoa in the lumen of seminiferous lobules (Corriero et al., 2007). The identification of germ cell types was performed on the basis of the detailed morphological description reported by Abascal et al. (2004), while the nomenclature was according to Schulz et al. (2010): undifferentiated type $A$ spermatogonia $\left(A_{\text {und }}\right)$, differentiated type $A$ spermatogonia $\left(A_{\text {diff }}\right)$, type $B$ spermatogonia, primary spermatocytes, secondary spermatocytes, spermatids and spermatozoa. All the germ cell types, except $A_{\text {und }}$ spermatogonia, are enveloped by Sertoli cells extensions that constitute the spermatocysts.

The detection of proliferating germ cells was performed on testicular samples from 40 individuals collected in May and June (20 captive and 20 wild), using the immunohistochemical localization of PCNA (Proliferating Cell Nuclear Antigen), a polymerase delta accessory protein that is synthesized in late $\mathrm{G} 1$ and $\mathrm{S}$ phases of the cell cycle and is, therefore, used as a nuclear marker of proliferation (Woods et al., 1991; McClusky, 2005). From testis samples embedded in paraffin wax, 5- $\mu$ m thick sections were cut, de-paraffinized in xylene, re-hydrated through graded ethanol solutions and pre-treated for 30 min with $0.3 \% \mathrm{H}_{2} \mathrm{O}_{2}$ in methanol to inhibit endogenous peroxidase activity. The sections were then incubated for 30 min in normal horse serum (NHS; Vector, Burlingame, CA, U.S.A.) diluted 1:50 in phosphate buffered saline (PBS; $0.01 \mathrm{M}$ phosphate buffer at $\mathrm{pH} 7.4$, containing $0.15 \mathrm{M} \mathrm{NaCl}$ ) to block non-specific binding sites for immunoglobulins. The sections were then incubated overnight at $4^{\circ} \mathrm{C}$ in a moist chamber with monoclonal antibodies to PCNA (ICN Pharmaceuticals, Milan, Italy) diluted $1: 25$ in PBS containing $0.1 \%$ bovine serum albumin. After rinsing for $10 \mathrm{~min}$ in PBS, the immunohistochemical visualization was carried out using the Vectastain Universal Elite Kit (Vector, Burlingame, CA, U.S.A.). This method utilizes the AvidinBiotin-Peroxidase complex procedure. Peroxidase activity was visualized by incubating for 10 min with Vector DAB Peroxidase Substrate Kit (Vector, Burlingame, CA, U.S.A), which produces a brown precipitate. To confirm the specificity of the immunostaining, a control-staining procedure were carried out by replacement of the primary antibody with NHS and PBS.

The detection of apoptotic germ cells in the testes was done on the same 40 individuals as above, by using the terminal deoxynucleotidyl transferase-mediated d'UTP nick end labelling (TUNEL) method. Apoptotic cell labelling was obtained on 5- $\mu \mathrm{m}$ thick sections by an In Situ Cell Death Detection Kit, AP (Roche Diagnostics, Mannheim, Germany) 
that was used in accordance with the manufacturer"s instructions. Prior to incubation with the reaction mixture, the sections, after their re-hydratation through graded ethanol solutions, were incubated in a permeabilization solution of $0.1 \%$ Triton $X-100$ in $0.1 \%$ sodium citrate for $8 \mathrm{~min}$ at $37^{\circ} \mathrm{C}$. Terminal deoxynucleotidyl transferase was diluted 1:10 in TUNEL Dilution Buffer (Roche Diagnostics, Mannheim, Germany). A ready to use solution of nitro blue tetrazolium chloride/ 5-bromo-4chloro-3indolyl phosphate, toluide salt (NBT/BCIP ) (Roche Diagnostics, Mannheim, Germany) was used as a substrate for the signal conversion.

\subsection{Measurement of seminiferous lobule diameter and quantification of germ cell proliferation and apoptosis}

At least 50 seminiferous lobules were selected randomly from the 40 testicular samples used for the germ-cell proliferation and apoptosis analyses described above. The seminiferous lobule diameter was measured on a digital field (surface area $=236181$ $\mu \mathrm{m}^{2}$ ), photographed with a 25X objective using a digital camera (DFC 420, Leica, Cambridge, U.K.) connected to a light microscope (DIAPLAN, Leitz, Wetzlar, Germany). Measurements were performed using an image analysis software (Leica Application Suite, version 3.3.0, Cambridge, U.K.).

The immunohistochemical method used for nuclear labeling of proliferating germ cells (anti PCNA immunostaining) did not allow distinguishing between the different cell types contained in spermatogonial cysts (type $A_{\text {diff }}$ and type $B$ spermatogonia), due to similarities in morphological and size characteristics, and the fact that the dye precipitated on the nuclei in the form of brownish patches. Therefore, for the quantification of germ cell proliferation the following cell categories were considered: single $A_{\text {und }}$ spermatogonia; spermatogonia making part of spermatocysts (type $A_{\text {diff }}$ and type B) and primary spermatocytes. The frequency of anti PCNA positive $A_{\text {und }}$ spermatogonia (number of cells per $\mathrm{mm}^{2}$ testis tissue), as well as the frequency of anti PCNA spermatogonial (type $A_{\text {diff }}$ and type $B$ ) and spermatocyte cysts (number of cysts per $\mathrm{mm}^{2}$ testis tissue) were measured in randomly selected digital fields. Three fields were taken for each of three sections per specimen. The three fields were chosen randomly using the following scheme: one field in the periphery of the testis section, close to the tunica albuginea; one in the middle part of the testis section; and one in the inner part, close to the duct system.

Due to the fragmentation of the apoptotic cells in ,apoptotic bodies" and their consequent phagocytosis (Young and Nelson, 2001), which made the individual identification of the cells involved in the apoptotic process difficult, the quantification of apoptosis was performed by measuring the surface occupied by TUNEL positive apoptotic structures (apoptotic cells + apoptotic bodies) $\left(\mu \mathrm{m}^{2}\right.$ per $\mathrm{mm}^{2}$ testis tissue).

All the measurements were performed on digital fields using the same image analysis system described above. 


\subsection{Evaluation of sperm motility characteristics}

Sperm concentration was measured using a Thoma hemocytometer after dilution of sperm by $500 \mathrm{X}$ in distilled water. Each Thoma cell consists of 400 squares of 0.0025 $\mathrm{mm}^{2}$ and a depth of $\left.100 \mu \mathrm{m}\right)$. After allowing $5 \mathrm{~min}$ for sedimentation of the spermatozoa in order to bring all of them on the same focal plane, three frames of 12 squares were recorded randomly through a video camera. The cells were then automatically counted using an image analysis software (Image J, NIH, USA).

In order to evaluate spermatozoa motility, sperm from the 5 captive fish sampled in Malta (Table 1) was activated by a two-step dilution according to Billard and Cosson (1992). The first dilution was 1:9 (v:v) in non-activating media made of $1 / 3$ seawater (osmotic pressure $300 \mathrm{mOsm}, \mathrm{pH} 8.2$ ). In order to trigger motility, $3.5 \mu \mathrm{l}$ of the diluted sperm were mixed with $1 \mathrm{ml}$ of seawater containing $0.25 \%$ Pluronic F-68 (Sigma Aldrich) in an Eppendorf microcentrifuge tube and an aliquot of $8 \mu \mathrm{l}$ was immediately introduced by capillarity between a Thoma counting cell and the cover slip. Pluronic F68 is a surfactant preventing the sticking of spermatozoa to the glass, thus allowing spermatozoa to swim freely until exhaustion without any attachment to the observation chamber. The total dilution of sperm was 1:2850. The counting cell was already focused under a video microscope (Axiolab Zeiss, Germany connected to a Sony SSCD50AP CCD video camera) at 20X magnification and set for dark field observation. The recording was launched at the exact time the motility was triggered. The drift of spermatozoa due to dispersal of the sample inside the Thoma cell ceased within the first ten seconds. The camera recorded 25 analog frames $\mathrm{s}^{-1}$, which were stored either on video tapes and digitalized later, or were digitalized directly and stored as computer files. The videos were sliced subsequently into sequences of frames by means of "Virtualdub" free software and then analyzed by CASA using the plugin developed by Wilson-Leedy and Ingermann (2007) for Image J (NIH, USA). After reproducibility control, the motility assessment was limited to $1 \mathrm{~s}$ analysis for every minute of movement until all movement ceased. The movement of spermatozoa from each sperm sample was recorded once. The motility analysis for one second allowed obtaining individual data from 25-35 spermatozoa, each spermatozoon being a replicate for the comparison of motility between males.

In order to check the quality of activating seawater and the possible involvement of calcium in sperm track shape and motility duration, which appeared to be abnormal, spermatozoa were activated successively using three different sources of seawater (1000 mOsm) from a recirculated water system, from the harbor and from offshore (tuna cages), respectively. In addition, spermatozoa were also activated using a calcium free medium composed of glucose $1 \mathrm{M}$, hepes $1 \mathrm{mM}$ at pH 8.2 (1000 mOsm), which has a similar osmolality to that of seawater. All these activating media included $0.25 \%$ Pluronic F-68, as described previously. The motility analyses were performed at controlled temperature $\left(24^{\circ} \mathrm{C}\right)$ in an air-conditioned laboratory, in order to run the analyses at water temperatures similar to those in the spawning cages at the time.

\subsection{Statistical analysis}

Among samples collected from wild and captive fish in June and May, mean values of (a) seminiferous lobule diameter, (b) number of anti PCNA positive $A_{\text {und }}$ spermatogonia,

(c) number of anti PCNA positive spermatogonial cysts, (d) number of anti PCNA 
positive spermatocyte cysts and (e) relative surface of apoptotic structures, were compared by ANOVA, followed by the Tukey-Kramer multiple-comparison test. Prior to the ANOVA test, the raw data of apoptotic surfaces were square root-transformed, as appropriate with surface data (Sokal and Rohlf, 1981). The variations of motility with time were assessed through a nested ANOVA design followed by the StudentNewman-Keuls test in order to evaluate possible individual male effect. The statistical analyses were performed using the MS Office Excel 2003 and Statistica software (Statsoft, Tulsa, Oklahoma, USA).

\section{Results}

\subsection{Histology analysis of the testes and detection of proliferating and apoptotic germ cells.}

At the beginning of the reproductive season in April the testes of captive fish were at early spermatogenesis: one individual possessed only $A_{\text {und }}, A_{\text {diff }}$ and type $B$ spermatogonia in the seminiferous lobules, whereas the germinal epithelium of the other five individuals was occupied by $A_{\text {und }}, A_{\text {diff }}$ and type $B$ spermatogonia, as well as cysts containing spermatocytes, spermatids or spermatozoa (Fig. 1a). Spermatozoa were sometimes observed in the testicular lobules and ducts. During May, all males sampled were in late spermatogenesis, with all stages of spermatogenesis being present in the germinal epithelium and the lumen of the seminiferous lobules often contained spermatozoa (Fig. 1b). All fish examined in June were mature, with the germinal epithelium constituted mainly of spermatogonia and the lumen of seminiferous lobules filled with spermatozoa (Fig. 1c). In July, all specimens observed were in a regressed ("spent") condition with the germinal epithelium consisting mainly of spermatogonia and residual spermatozoa in the lumen (Fig. 1d). The histological appearance of the testes of wild specimens captured in May and June by tuna traps in the island of San Pietro (Italy) and Kenitra (Morocco) were similar to that of captive individuals sampled in the same period.

Immunolocalization of PCNA in proliferating germ cells was detected in type $A_{\text {und }}$ spermatogonia, as well as cysts containing type $A_{\text {diff }}$ spermatogonia, type $B$ spermatogonia and primary spermatocytes (Fig. 2a). A weak staining of the nuclei of secondary spermatocytes was also observed, however these cells were not quantified. Identification of apoptotic germ cells in Atlantic bluefin tuna was detectd mainly in $A_{u n d}$, $A_{\text {diff }}$ and type B spermatogonia, and primary spermatocytes (Fig. 2b).

\subsection{Comparative analysis of seminiferous lobule diameter, proliferating and apoptotic germ cells in captive and wild individuals.}

No statistical difference $(P>>0.05)$ was found in seminiferous lobule diameter between testes during the spermatogenesis (May) and spawning (June) periods, either in captive $(145.0 \pm 13.7 \mu \mathrm{m} v s 140.0 \pm 6.4 \mu \mathrm{m})$ or in wild fish $(147.1 \pm 9.0 \mu \mathrm{m} v s 139.5 \pm 8.6 \mu \mathrm{m})$ (Fig. 3). The mean diameter of seminiferous lobules of captive individuals was comparable $(P>>0.05)$ to wild ones both in spermatogenesis $(145.0 \pm 13.7 \mu \mathrm{m} v \mathrm{~s}$ $147.1 \pm 9.0 \mu \mathrm{m})$ and spawning (140.0 $\pm 6.4 \mu \mathrm{m}$ vs $139.5 \pm 8.6 \mu \mathrm{m})$ stages (Fig. 3). 
In captive individuals the number of anti PCNA positive $A_{\text {und }}$ spermatogonia was significantly higher $(P<0.01)$ during the spermatogenesis period with respect to the spawning stage; the same pattern was found for wild fish in the two periods $(P<0.05)$ (Fig. 4a). When compared with wild individuals during spermatogenesis, captive fish showed a significantly $(P<0.01)$ higher number of anti PCNA positive $A_{\text {und }}$ spermatogonia, whereas no difference between the two groups was recorded during the spawning period (Fig. 4a). Only captive fish showed significant difference in the density of anti PCNA positive spermatogonial cysts between the spermatogenesis and spawning periods $(P<0.05)($ Fig. $4 b)$. This parameter was significantly higher in captive fish compared to wild in May $(P<0.01)$, whereas in June the density of anti PCNA positive spermatogonial cysts was close to zero in both groups (Fig. 4b).

A significantly higher density of anti PCNA positive spermatocyte cysts was observed in the spermatogenesis period with respect to the spawning period in captive $(P<0.05)$, but not in wild individuals (Fig. 4 c). Wild specimens had a significantly higher density of anti PCNA positive spermatocyte cysts than captive ones in May $(P<0.05)$, but not in June (Fig. 4c).

The relative surface of germinal epithelium occupied by apoptotic structures increased significantly from May to June, both in captive $(P<0.05)$ and wild individuals $(P<0.05)$ (Fig. 5). The density of apoptotic structures was significantly higher in captive than in wild fish during both the spermatogenesis $(P<0.05)$ and spawning periods $(P<0.05)$ (Fig. 5).

\subsection{Sperm concentration and motility}

Mean $( \pm S E)$ sperm concentration of captive Atlantic bluefin tuna was $4.29 \pm 0.42 \times 10^{10}$ spermatozoa $\mathrm{ml}^{-1}$. The percentage of motile sperm was highest immediately after activation and then decreased rapidly (Fig. 6). The total duration of motility from the activation to the time when any progressive movement ceased was around $1 \mathrm{~min}$, irrespective of the origin of seawater (data not shown). The average path velocity (VAP) of the spermatozoa was about $150 \mu \mathrm{m} \mathrm{s}^{-1}$, was stable for the first $20 \mathrm{~s}$ and decreased progressively thereafter (Fig. 7). The nested ANOVA with time and individuals as factors of variation showed, as expected, a significant decrease of VAP with time after activation $(P<0.01)$ and a significant difference among males $(P<0.01)$, with interaction indicating that the decrease of VAP proceeded differently between males $(P<0.01)$.

Once activated in seawater of any of the three sources, the spermatozoa proceeded in a circular motion, with a small diameter preventing progressive forward movement (Fig. $8 \mathrm{~A})$. On the contrary, when activated in a solution of $1 \mathrm{M}$ glucose, spermatozoa exhibited straight line forward motility (Fig. 8B) and did not show significant difference in motility duration and mean VAP compared to those activated by seawater (data not shown). 
Only a few reports on the reproductive cycle of male tunas have been published so far (Ratty et al., 1990; Schaefer, 1996, 2001) and information on Atlantic bluefin tuna spermatogenesis in the Mediterranean Sea is equally sparse. So far, studies have reported on the morphology and ultrastructure of the testes of migrant and spawning specimens from the eastern Atlantic and western Mediterranean Sea (Abascal et al., 2004) and the description of the testicular cycle of individuals sampled in the western and central Mediterranean Sea (Santamaria et al., 2003). According to the latter study, Atlantic bluefin tuna testes were in a quiescent stage in February and March; from April to early May the testes were in an early stage of spermatogenesis; in mid May active spermatogenesis took place in the gonads; from late May to early July seminiferous tubules were filled with spermatozoa, showing a mature condition, and thereafter the testes were in a regressed phase with only residual spermatozoa in the tubules. Based on the histological appearance of the testes examined in the present study, the spermatogenetic cycle of Atlantic bluefin tuna reared in captivity at three different sites coincided well with that of wild Atlantic bluefin tuna (Santamaria et al., 2003). The apparent synchronicity of reproductive function in captive Atlantic bluefin tuna is encouraging for the efforts to establish captive broodstocks of Atlantic bluefin tuna, indicating that the undertaking of an annual migration is not a prerequisite for the reproductive maturation of Atlantic bluefin tuna. In addition, it appears that the annual water temperature profile to which the fish are exposed in a stationary sea cage located in coastal waters may be representative of the temperature preferences of wild Atlantic bluefin tuna migrating to their spawning sites (Block et al., 2001, 2005). Among environmental parameters, the influence of temperature on fish gametogenesis has been documented well (Billard, 1986; Nóbrega et al., 2009; Schulz et al., 2010).

Nevertheless, although spermatogenesis in captivity coincided with the normal reproductive season, the existence of some impairment in the spermatogenetic process of captive Atlantic bluefin tuna has already been reported (Corriero et al., 2009). For example, after 1-3 years in captivity Atlantic bluefin tuna males had lower GSI values and diameter of seminiferous lobules during the spawning season than wild spawners In the present study, proliferating spermatogonia were observed throughout the testis, from the periphery to the middle of the testis, which is the typical characteristic of the "unrestricted spermatogonial" testis type (Grier et al., 1980). In May the proliferation rate of spermatogonia (both stem and differentiated cells) of captive fish was higher than that of wild ones, while the amount of meiotic cysts was lower. In June the spermatogonia proliferation, as well as density of meiotic cysts were higher in captive fish than in wild spawners. Altogether, the comparison of germ cell proliferation data between captive and wild Atlantic bluefin tuna indicated a clear shift of the whole spermatogenetic process in captivity, with a high spermatogonial division in May and predominance of meiosis in June, when the wild spawners were in the last phase of spermatogenesis (i.e. spermiogenesis phase) with prevalence of spermatids and spermatozoa. These results suggest that the captive-rearing condition in a species used to perform wide trophic and reproductive migrations, such as the Atlantic bluefin tuna (Block et al., 2001, 2005), might be responsible for an alteration of testis activity.

Apoptotic germ cells, both spermatogonia and primary spermatocytes, were localized in all examined histological sections of Atlantic bluefin tuna testes. This finding is in 
agreement with our previous study in the same species (Corriero et al., 2009), with another large pelagic fish such as the swordfish Xiphias gladius (Corriero et al., 2007) and with a freshwater species like the goby Padogobius martensi (Cinquetti and Dramis, 2003). As already reported for the wild adult swordfish (Corriero et al., 2007), the occurrence of apoptosis in captive Atlantic bluefin tuna was higher during the maximum spermatogenic activity (May) than both in the recrudescence (April, data not shown) and in the spawning periods (June). This finding seems to confirm a role of apoptosis in the quantitative control of germ cell population, as well as in the prevention of the maturation of aberrant germ cells. Different hypotheses have been proposed regarding the fate of apoptotic cells in the fish testis: phagocytosis by macrophages, phagocytosis by Sertoli cells or elimination through the sperm duct system (Billard et al., 1972; Grier, 1993; Cinquetti and Dramis, 2003; Corriero et al., 2007). In the present study, macrophages in the germinal epithelium were not detected, while luminal apoptotic cells or bodies were often observed (data not shown), so that the possibility that apoptotic cells may be voided through the genital tract seems to be the most likely.

Germ cell apoptotic density was significantly higher in captive than in wild Atlantic bluefin tuna both in May and June. In many fishes, the principal androgen that stimulates spermatogenesis is 11-ketotestosterone and, to a lesser extent, testosterone (Kime and Manning, 1982; Borg, 1994; Weltzien et al., 2002). There are no studies on the role of androgens in fish germ cell apoptosis; however in mammals testosterone acts as a cell survival factor for germ cells (Young and Nelson, 2001). Withdrawal of testosterone induces apoptosis in the testis (Nandi et al., 1999; Woolveridge et al., 1999) and reintroduction of this steroid hormone can reduce apoptotic cell death (Nandi et al., 1999). The role of androgens, particularly of 11-ketotestosterone, as germ cell survival factor, has been already hypothesized in Atlantic bluefin tuna (Corriero et al., 2009). It is known that many fishes reared in captivity, including Atlantic bluefin tuna, display some kind of reproductive dysfunctions and these anomalies are commonly ascribed to captivity-induced stress. The influence of stress on the functioning of the reproductive axis has been amply demonstrated in all vertebrate classes, including humans (Rabin et al., 1988), non-human mammals (Huhman et al., 1991), birds (Petitte and Etches, 1991), reptiles (Elsey et al., 1991), amphibians (Licht et al., 1983), and fishes (Schreck, 1981; 2000; 2010). The hormones involved in the stress response include the catecholamines and the hormones of the hypothalamic-pituitary-interrenal axis (Basrur et al., 2010; Schreck, 2010; Zahl et al., 2010). The effects of stress on the reproductive axis are mediated mainly by corticosteroids, which can have a suppressive activity on the functions of the hypothalamus (Moore and Zoeller, 1985), pituitary (Brann et al., 1990), and gonads (Sapolsky, 1985; Carragher and Sumpter, 1990). In female rainbow trout Oncorhynchus mykiss, cortisol-mediated stress affects testosterone (T) synthesis and cortisol administration can be responsible for a reduction in plasma $\mathrm{T}$ and estradiol $17 \beta\left(E_{2}\right)$ levels (Pankhurst and Van Der Kraak, 2000). In pre-pubertal common carp Cyprinus carpio chronically elevated cortisol levels affected all the components of the brain-pituitary-gonad axis and caused a delay of the first wave of spermatogenesis (Goos and Consten, 2002). In captive Atlantic bluefin tuna, the administration of $\mathrm{GnRHa}$ through a controlled-release delivery system (Mylonas et al., 2007) was correlated with an increase of plasma LH levels, as well as 11-KT (Rosenfeld et al., 2012). The detection of a lower density of apoptotic germ cells in GnRHa-treated fish was attributed to this increase of testicular 11-ketotestosterone production, which was stimulated by the GnRHa-induced LH release from the pituitary (Corriero et al., 2009). It may be speculated that the differences observed in apoptotic 
rates between wild and captive fish may be due to differences in their corresponding plasma levels of $11-\mathrm{KT}$, but this cannot be confirmed since no blood could be obtained from the wild fish.

Evaluations of sperm motility characteristics of wild tuna are extremely limited (Doi et al., 1982, Mylonas et al., 2007, Suquet et al., 2010) to a large extend because sperm analyses performed onboard are difficult or impossible. In the present study, the captive tuna sampling protocol and the proximity of the broodstock maintenance site to a land-based laboratory offered the opportunity, for the first time, to provide information on Atlantic bluefin tuna sperm motility characteristics. In addition, these sperm characteristics could be associated to the reproductive status of the individual as evaluated by histological examinations, discussed above. Based on the documented increased germ cell apoptosis, which corresponds to a decreased germ cell output, in the present study one would have expected a corresponding decrease in spermatozoa concentration in the semen. However, the obtained data did not reveal any differences in spermatozoa concentration in comparison with another stock of captive Atlantic bluefin tuna reared in sea cages in Spain (Mylonas et al., 2007) or with wild individuals captured in Sicilian waters (Doi et al., 1982). Similar ranges of spermatozoa concentration were generally observed in other fish specie, which exhibit very short motility period, such as the European sea bass Dicentrarchus labrax and salmonids (Suquet et al., 1994), while lower sperm counts were recorded in species with long motility period, such as turbot Scophthalmus maximus (Suquet et al., 1994) and hake Merluccius merluccius (Groison et al., 2010).

In most marine fishes, sperm is activated by seawater through the increase of osmotic pressure in cell microenvironment. All the spermatozoa usually start moving (activation) at high velocities, at the same time. Following activation, the percentage of motile spermatozoa decreases progressively, concomitantly to a decrease of flagellar beat frequency and speed, until the cessation of any movement as a result of energy depletion (Cosson et al., 2008). Moreover, spermatozoa trajectories are linear-like at activation, becoming progressively curvilinear due to asymmetric waves of flagellum beat, as shown in the sea urchin Strongylocentrotus purpuratus (Brokaw, 1991) and in the European sea bass (Dreanno et al., 1999). In the present study, spermatozoa movement from captive Atlantic bluefin tuna exhibited the general features of other marine fishes, though the timing of the changes was contracted. Spermatozoa immediately after activation swam following circular trajectories, without any forward progress and the duration of motility was very short. Although the results were homogenous in the studied population, the sperm motility characteristics observed and analyzed in the present work were not consistent with those reported for wild (Doi et al., 1982) or captive individuals (unpublished and Suquet et al., 2010), which showed motility duration of 14 to 20 minutes -values that are ten times greater than in the present study.

The activation of sperm by osmotic pressure is mediated by ion exchanges through the flagellum membrane (Morisawa, 1994) and internal $\mathrm{Ca}^{++}$concentration, which is itself dependent on external $\mathrm{Ca}^{++}$concentration (Cosson et al., 2008). Variations in internal $\mathrm{Ca}^{++}$generate asymmetry in flagellum waves, resulting in curved spermatozoa trajectories (Dreanno et al., 1999). Activation of Atlantic bluefin tuna spermatozoa motility by means of 1000 mOsm glucose solution mimicked seawater activation without increasing $\mathrm{Ca}^{++}$availability, and was able to trigger motility with straight trajectories, but 
did not increase significantly motility duration. Although the present results document that captive Atlantic bluefin tuna spermatozoa motility is not consistent with previous observations in wild fish, it is not possible at this stage to point to specific causes, but calcium regulation defects and low energy stores may be involved.

In conclusion, the present study suggests that spermatogenesis may be somewhat impaired in captive Atlantic bluefin tuna, as germ cell proliferation seems to be reduced and delayed, germ cell apoptosis appears increased and sperm motility anomalous both in terms of duration and swimming efficiency. Further studies are necessary to determine the exact causes of this alteration to the spermatogenetic process, possibly caused by an endocrine dysfunction along the reproductive axis, in particular due to an insufficient pituitary stimulation from hypothalamic $\mathrm{GnRH}$, which in turn might depend on suboptimal environmental conditions at the rearing sites, as well as on captivityinduced stress. Nevertheless, the recent production of large numbers of fertilized and viable eggs from captive Atlantic bluefin tuna broodstocks (De Metrio et al., 2010; de la Gandara et al., 2011), suggests that even with the above impairments in the reproductive function of the males, it is feasible to obtain spawns of good quality under captive conditions.

\section{Acknowledgements}

The authors wish to tank M. Losurdo, E. Pesola, A. Marinelli and A. Disabato for their technical assistance. We are grateful to Mare Nostro Srl and his owner E. Ceravolo and to the boat crew and divers of Tuna Graso, S.A. Special thanks are also due to A. Belmonte-Ríos and R. Vassallo-Agius who made the sampling in Cartagena and Malta possible. This work has been carried out with financial support from the Commission of the European Communities, specific RTD programme of Framework Programme 7, Theme 2-Food, Agriculture, Fisheries and Biotechnology (Project SELFDOTT, grant number 212797). It does not necessarily reflect its views and in no way anticipates the Commission's future policy in this area.

\section{References}

Abascal, F. J.; Megina, C.; Medina, A., 2004: Testicular development in migrant and spawning bluefin tuna (Thunnus thynnus (L.)) from the eastern Atlantic and Mediterranean. Fish. Bull. 102, 407-417.

Amann, R. P.; Katz, D. F., 2004: Reflections on CASA after 25 years. J. Androl. 25, 317-325.

Anonymous, 2006a: Atlantic bluefin tuna. In: ICCAT report for biennial period, 2006-07, Part I, Madrid 2007, pp. 98-114.

Anonymous, 2006b: Ethical justification for the use and treatment of fishes in research. J. Fish Biol. 68, 1-2.

Basrur, T. V.; Longland, R.; Wilkinson, R. J., 2010: Effects of repeated crowding on the stress response and growth performance in Atlantic salmon (Salmo salar). Fish Physiol. Biochem 36, 445-450.

Billard, R., 1986: Spermatogenesis and spermatology of some teleost fish species. Reprod. Nutr. Dev. 26, 877-920. 
Billard, R.; Cosson, M. P., 1992: Some problems related to the assessment of sperm motility in freshwater fish. J. Exp. Zool. Part A 261, 122-131.

Billard, R.; Jalabert, B.; Breton, B., 1972: Les cellules de Sertoli des poissons téléostéens. Ann. Biol. Anim. Biochim. Biophys. 12, 19-32.

Blanco-Rodríguez, J.; Martínez-García, C., 1996: Spontaneous germ cell death in the testis of the adult rat takes the form of apoptosis: re-evaluation of cell types that exhibit the ability to die during spermatogenesis. Cell Proliferat. 29, 13-31.

Block, B. A.; Dewar, H.; Blackwell, S. B.; Williams, T. D.; Prince, E. D.; Farwell, C. J.; Boustany, A.; Teo, S. L. H.; Seitz, A.; Walli, A.; Fudge, D., 2001: Migratory movements, depth preferences, and thermal biology of Atlantic bluefin tuna. Science 293, 1310-1314.

Block, B. A.; Teo, S. L. H.; Walli, A.; Boustany, A.; Stokesbury, M. J. W.; Farwell, C. J.; Weng, K. C.; Dewar, H.; Williams, T. D., 2005: Electronic tagging and population structure of Atlantic bluefin tuna. Nature 434, 1121-1127.

Bobe, J.; Labbé, C., 2010: Egg and sperm quality in fish. Gen. Comp. Endocrinol. 165, 535-548.

Borg, B., 1994: Androgens in teleost fishes. Comp. Biochem. Physiol. 109C, 219-245.

Brann, D. W.; Putnam, C. D.; Mahesh, V. B., 1990: Corticosteroid regulation of gonadotropin and prolactin secretion in the rat. Endocrinology 126, 159-166.

Brokaw, C. J., 1991: Calcium sensors in sea urchin sperm flagella. Cell Motil. Cytoskel. 18, 123-130.

Cabrita, E.; Robles, V.; Herráez, P., 2009: Sperm quality assessment. In: Methods in Reproductive Aquaculture. Marine and Freshwater Species. Eds: E. Cabrita; V. Robles; P. Herráez. CRC Press Taylor \& Francis Group, Boca Raton, USA, pp. 93-148.

Carragher, J. F.; Sumpter, J. P., 1990: The effect of cortisol on the secretion of sex steroids from cultured ovarian follicles of rainbow trout. Gen. Comp. Endocr. 77, 403-407.

Cheng, C. Y.; Wong, E. W. P.; Yan, H. H. N.; Mruk, D. D., 2010: Regulation of spermatogenesis in the microenvironment of the seminiferous epithelium: new insights and advances. Mol. Cell. Endocrinol. 315, 49-56.

Cinquetti, R.; Dramis, L., 2003: Histological, histochemical, enzyme histochemical and ultrastructural investigations of the testis of Padogobius martensi between annual breeding seasons. J. Fish Biol. 63, 1402-1428.

Corriero, A.; Desantis, S.; Bridges, C. R.; Kime, D. E.; Megalofonou, P.; Santamaria, N.; Cirillo, F.; Ventriglia, G.; Di Summa, A.; Deflorio, M.; Campobasso, F.; De Metrio, G., 2007: Germ cell proliferation and apoptosis during different phases of swordfish (Xiphias gladius L.) spermatogenetic cycle. J. Fish Biol. 70, 83-99.

Corriero, A.; Medina, A.; Mylonas, C. C.; Abascal, F. J.; Deflorio, M.; Aragón, L.; Bridges, C. R.; Santamaria, N.; Heinisch, G.; Vassallo-Agius, R.; Belmonte-Ríos, A.; Fauvel, C.; García, A.; Gordin, H.; De Metrio, G., 2007: Histological study of the effects of treatment with gonadotropin-releasing hormone agonist ( $\mathrm{GnRHa}$ ) on the reproductive maturation of captive-reared Atlantic bluefin tuna (Thunnus thynnus L.). Aquaculture 272, 675-686.

Corriero, A.; Medina, A.; Mylonas, C. C.; Bridges, C. R.; Santamaria, N.; Deflorio, M.; Losurdo, M.; Zupa, R.; Gordin, H.; de la Gándara, F.; Belmonte-Ríos, A.; Pousis, C.; De Metrio, G., 2009: Proliferation and apoptosis of male germ cells in captive Atlantic bluefin tuna (Thunnus thynnus L.) treated with gonadotropin-releasing hormone agonist (GnRHa). Anim. Reprod. Sci. 116, 346-357. 
Cosson, J.; Groison, A. L.; Suquet, M.; Fauvel, C.; Dreanno, C.; Billard, R., 2008: Marine fish spermatozoa: racing ephemeral swimmers. Reproduction 136, 277-294.

de la Gándara, F.; Ortega, A.; Belmonte, A.; Mylonas, C. C., 2011: Spontaneous spawning of Atlantic bluefin tuna Thunnus thynnus kept in captivity. Aquaculture Europe 2011, October, Rhodes, Greece. pp. 19-21.

De Metrio, G.; Bridges, C. R.; Mylonas, C. C.; Caggiano, M.; Deflorio, M.; Santamaria, N.; Zupa, R.; Pousis, C.; Vassallo-Agius, R.; Gordin, H.; Corriero, A., 2010: Spawning induction and large-scale collection of fertilized eggs in captive Atlantic bluefin tuna (Thunnus thynnus L.) and the first larval rearing efforts. J. Appl. Ichthyol. 26, 596-599.

Doi, M.; Hoshino, T.; Taki, Y.; Ogasawara, Y., 1982: Activity of the sperm of the bluefin tuna Thunnus thynnus under fresh and preserved conditions. Bull. Jap. Soc. Sci. Fish. 48, 495-498.

Dreanno, C.; Cosson, J.; Suquet, M.; Cibert, C.; Fauvel, C.; Dorange, G.; Billard, R., 1999: Effects of osmolality, morphology perturbations and intracellular nucleotide content during the movement of sea bass (Dicentrarchus labrax) spermatozoa. J. Reprod. Fertil. 116, 113-125.

EEC., 1986: Council Directive 86/609 EEC for the protection of animals used for experimental and other scientific purposes. Official Journal L358, 1-28.

Elsey, R. M.; Lance, V. A.; Joanen, T.; Mcnease, L., 1991: Acute stress suppresses plasma estradiol levels in female alligators (Alligator mississippiensis). Comp. Biochem. Phys. A 100, 649-652.

Goos, H. J. Th.; Consten, D., 2002: Stress adaptation, cortisol and pubertal development in the male common carp, Cyprinus carpio. Mol. Cell. Endocrinol. 197, 105-116.

Grier, H. J., 1993: Comparative organization of Sertoli cells including the Sertoli cell barrier. In: The Sertoli cell. Eds: L. D. Russell; M. D. Griswold. Cache River Press, Clearwater, FL, pp. 703-739.

Grier, H. J.; Linton, J. R.; Leatherland, J. F.; De Vlaming, V. L., 1980: Structural evidence for two different testicular types in teleost fishes. Am. J. Anat. 159, 331-345.

Groison, A. L.; Fauvel, C.; Suquet, M.; Kjesbu, O. S.; Le Coz, J. R.; Mayer, I.; Cosson, J., 2010: Some characteristics of sperm motility in European hake (Merluccius merluccius, L., 1758). J. Appl. Ichthyol. 26, 682-689.

Huhman, K. L.; Moore, T. O.; Ferris, C. F.; Mougey, E. H.; Meyerhoff, J. L., 1991: Acute and repeated exposure to social conflict in male golden hamsters: Increases in plasma POMC peptides and cortisol and decreases in plasma testosterone. Horm. Behav. 25, 206-216.

Kime, D. A.; Manning, N. J., 1982: Seasonal patterns of free and conjugated androgens in the brown trout Salmo trutta. Gen. Comp. Endocrinol. 48, 222-231.

Licht, P.; McCreery, B. R.; Barnes, R.; Pang, R., 1983: Seasonal and stress related changes in plasma gonadotropins, sex steroids, and corticosterone in the bullfrog, Rana catesbeiana. Gen. Comp. Endocrinol. 50, 124-145.

McClusky, L. M., 2005: Stage and season effects on cell cycle and apoptotic activities of germ cells and Sertoli cells during spermatogenesis in the spiny dogfish (Squalus acanthias). Reproduction 129, 89-102.

Moore, F. L.; Zoeller, R. T., 1985: Stress-induced inhibition of reproduction: Evidence of suppressed secretion of LH-RH in an amphibian. Gen. Comp. Endocr. 60, 252-258. 
Morisawa, M., 1994: Cell signaling mechanisms for sperm motility. Zool. Sci. 11, 647-662.

Mylonas, C. C.; Bridges, C. R.; Gordin, H.; Belmonte-Ríos, A.; García, A.; de la Gándara, F.; Fauvel, C.; Suquet, M.; Medina, A.; Papadaki, M.; Heinisch, G.; De Metrio, G.; Corriero, A.; Vassallo-Agius, R.; Guzmán, J. M.; Mañanos, E.; Zohar, Y., 2007: Preparation and administration of gonadotropin-releasing hormone agonist $(\mathrm{GnRHa})$ implants for the artificial control of reproductive maturation in captive-reared Atlantic bluefin tuna (Thunnus thynnus thynnus). Rev. Fish. Sci. $15,183-210$.

Mylonas, C. C.; de la Gándara, F.; Corriero, A.; Belmonte-Ríos, A., 2010: Atlantic bluefin tuna (Thunnus thynnus) farming and fattening in the Mediterranean Sea. Rev. Fish. Sci. 18, 266-280.

Mylonas, C. C.; Fostier, A.; Zanuy, S., 2010: Broodstock management and hormonal manipulations of fish reproduction. Gen. Comp. Endocrinol. 165, 516-534.

Mylonas, C. C.; Zohar, Y., 2007: Promoting oocyte maturation, ovulation and spawning in farmed fish. In: The Fish Oocyte: From Basic Studies to Biotechnological Applications. Eds: P. J. Babin; J. Cerdá; E. Lubzens. Kluwer Academic Publishers, Dordrecht, The Netherlands, pp. 433-470.

Mylonas, C. C.; Zohar, Y., 2008: Controlling reproduction in aquaculture. In: New Technologies in Aquaculture: Improving Production Efficiency, Quality and Environmental Management. Eds: G. Burnell; G. Allan. Woodhead Publishing Ltd, Cambridge, UK, pp. 1-38.

Nandi, S.; Banerjee, P. P.; Zirkin, B. R., 1999: Germ cell apoptosis in the testes of Sprague Dawley rats following testosterone withdrawal by ethane 1,2dimethanesulfonate administration: relationship to Fas?. Biol. Reprod. 61, 70-75.

Nóbrega, R. H.; Batlouni, S. R.; França, L. R., 2009: An overview of functional and stereological evaluation of spermatogenesis and germ cell transplantation in fish. Fish Physiol. Biochem. 35, 197-206.

Pankhurst, N. W.; Van Der Kraak, G., 2000: Evidence that acute stress inhibits ovarian steroidogenesis in rainbow trout in Vivo, through the action of cortisol. Gen. Comp. Endocrinol. 117, 225-237.

Petitte, J. N.; Etches, R. J., 1991: Daily infusion of corticosterone and reproductive function in the domestic hen (Gallus domesticus). Gen. Comp. Endocr. 83, 397-405.

Prisco, M.; Liguoro, A.; Comitato, R.; Cardone, A.; D"Onghia, B.; Ricchiari, L.; Angelini, F.; Andreuccetti, P., 2003: Apoptosis during spermatogenesis in the spotted ray Torpedo marmorata. Mol. Reprod. Dev. 64, 341-348.

Rabin, D. S.; Gold, P. W.; Margioris, A. N.; Chrousos, G. P., 1988: Stress and reproduction: physiologic and pathophysiologic interactions between the stress and reproductive axes. Adv. Exp. Med. Biol. 245, 377-387.

Ratty, F. J.; Laurs, R. M.; Kelly, R. M., 1990: Gonad morphology, histology, and spermatogenesis in south Pacific albacore tuna Thunnus alalunga (Scombridae). Fish. Bull. 88, 207-216.

Rosenfeld, H.; Mylonas, C. C.; Bridges, C. R.; Heinisch, G.; Corriero, A.; VassalloAgius, R.; Medina, A.; Belmonte, A.; Garcia, A.; de la Gándara, F.; Fauvel, C.; De Metrio, G.; Meiri-Ashkenazi, I.; Gordin, H.; Zohar, Y., 2012: GnRHa-mediated stimulation of the reproductive endocrine axis in captive Atlantic bluefin tuna, Thunnus thynnus. Gen. Comp. Endocrinol. 175, 55-64. 
Rurangwa, E.; Kime, D. E.; Ollevier, F.; Nash, J. P., 2004: The measurement of sperm motility and factors affecting sperm quality in cultured fish. Aquaculture 234, $1-28$.

Santamaria, N.; Corriero, A.; Desantis, S.; Zubani, D.; Gentile, R.; Sciscioli, V.; de la Serna, M.; Bridges, C. R.; De Metrio, G., 2003: Testicular cycle of the Mediterranean bluefin tuna (Thunnus thynnus L.). Cah. Opt. Med. 60, 183-185.

Sapolsky, R. M., 1985: Stress-induced suppression of testicular function in the wild baboon: role of glucocorticoids. Endocrinology 116, 2273-2278.

Schaefer, K. M., 1996: Spawning time, frequency, and batch fecundity of yellowfin tuna, Thunnus albacares, near Clipperton Atoll in the eastern Pacific Ocean. Fish. Bull. 94, 98-112.

Schaefer, K. M., 2001: Reproductive biology of tunas. In: Tuna: Physiology, Ecology, and Evolution. Eds: B. A. Block; E. D. Stevens. Academic Press, San Diego, pp. 225-270.

Schreck, C. B., 1981: Stress and compensation in teleostean fishes: response to social and physical factors. In: Stress and Fish. Ed: A. D. Pickering. Academic Press, London/New York, pp. 295-321.

Schreck, C. B., 2000: Accumulation and long-term effects of stress in fish. In: The Biology of Animal Stress: basic principles and implications for animal welfare. Eds: G. P. Moberg; J. A. Mench. CABI Publishing, Wallingford, UK, pp. 147-158.

Schreck, C. B., 2010: Stress and fish reproduction: The roles of allostasis and hormesis. Gen. Comp. Endocrinol. 165, 549-556.

Schulz, R. W.; de França, L. R.; Lareyre, J-J.; LeGac, F.; Chiarini-García, H.; Nóbrega, R. H.; Miura, T., 2010: Spermatogenesis in fish. Gen. Comp. Endocrinol. 165, 390-411.

Schulz, R. W.; Miura, T., 2002: Spermatogenesis and its endocrine regulation. Fish Physiol. Biochem. 26, 43-56.

Sharpe, R. M., 1994: Regulation of spermatogenesis. In: The Physiology of Reproduction. Eds: E. Knobil; J. D. Neill. Raven Press, New York, pp. 1363-1434.

Sokal, R. R.; Rohlf, F. J., 1981: Biometry: the principles and practice of statistics in biological research. Freeman WH and Company, New York, p. 859.

Suquet, M.; Billard, R.; Cosson, J.; Dorange, G.; Chauvaud, L.; Mugnier, C.; Fauvel, C., 1994: Sperm features in turbot (Scophthalmus maximus): a comparison with other freshwater and marine fish species. Aquat. Living Resour. 7, 283-294.

Suquet, M.; Cosson, J.; de la Gándara, F.; Mylonas, C. C.; Papadaki, M.; Lallemant, S.; Fauvel, C., 2010: Sperm features of captive Atlantic bluefin tuna (Thunnus thynnus). J. Appl. Ichthyol. 26, 775-778.

Weltzien, F. A.; Taranger, G. L.; Karlsen, Ø.; Norberg, B., 2002: Spermatogenesis and related androgen levels in Atlantic halibut (Hippoglossus hippoglossus L.). Comp. Biochem. Physiol. Part A 132, 567-575.

Wilson-Leedy, J. G.; Ingermann, R. L., 2007: Development of a novel CASA system based on open source software for characterization of zebrafish sperm motility parameters. Theriogenology 67, 661-672.

Woods, A. L.; Hall, P. A.; Shepherd, N. A.; Hanby, A. M.; Waseem, N. H.; Lane, D. P.; Levison, D. A., 1991: The assessment of proliferating cell nuclear antigen (PCNA) immunostaining in primary gastrointestinal lymphomas and its relationship to histological grade, $\mathrm{S}+\mathrm{G} 2+\mathrm{M}$ phase fraction (flow cytometric analysis) and prognosis. Histopathology 19, 21-28. 
Woolveridge, I.; de Boer-Brouwer, M.; Taylor, M. F.; Teerds, K. J.; Wu, F. C. W.; Morris, I. D., 1999: Apoptosis in the rat spermatogenic epithelium following androgen withdrawal: changes in apoptosis-related genes. Biol. Reprod. 60, 461-470.

Young, K. A.; Nelson, R. J., 2001: Mediation of seasonal testicular regression by apoptosis. Reproduction 122, 677-685.

Zahl, I. H.; Kiessling, A.; Samuelsen, O. B.; Olsen, R. E., 2010: Anesthesia induces stress in Atlantic salmon (Salmo salar), Atlantic cod (Gadus morhua) and Atlantic halibut (Hippoglossus hippoglossus). Fish Physiol. Biochem. 36, 719-730.

Zohar. Y.; Mylonas, C. C., 2001: Endocrine manipulations of spawning in cultured fish: from hormones to genes. Aquaculture 197, 99-136. 


\section{Tables}

Table 1 - Biometric data of captive and wild adult Atlantic bluefin tuna sampled from different sites in the Mediterranean region.

\begin{tabular}{|c|c|c|c|c|}
\hline State & Month & $\begin{array}{l}\text { Geographical } \\
\text { location }\end{array}$ & $\begin{array}{c}\text { Curved Fork } \\
\text { length } \\
\left(\mathrm{CF}_{\mathrm{L}}, \mathrm{cm}\right) \\
\end{array}$ & $\begin{array}{l}\text { Body mass } \\
\left(\mathrm{M}_{\mathrm{B}}, \mathrm{kg}\right)\end{array}$ \\
\hline \multirow{6}{*}{ Captive } & \multirow{6}{*}{ April } & \multirow{6}{*}{$\begin{array}{l}\text { Cartagena } \\
\text { (Spain) }\end{array}$} & 132 & 38 \\
\hline & & & 134 & 41 \\
\hline & & & 139 & 50 \\
\hline & & & 147 & 57 \\
\hline & & & 149 & 61 \\
\hline & & & 149 & 60 \\
\hline \multirow{8}{*}{ Captive } & \multirow{8}{*}{ May } & \multirow{8}{*}{$\begin{array}{c}\text { Cartagena } \\
\text { (Spain) }\end{array}$} & 128 & 46 \\
\hline & & & 132 & 51 \\
\hline & & & 134 & 51 \\
\hline & & & 135 & 48 \\
\hline & & & 138 & 62 \\
\hline & & & 139 & 57 \\
\hline & & & 145 & 63 \\
\hline & & & 146 & 53 \\
\hline \multirow{12}{*}{ Captive } & \multirow{12}{*}{ June } & \multirow{5}{*}{ Malta } & 152 & 68 \\
\hline & & & 155 & 64 \\
\hline & & & 157 & 74 \\
\hline & & & 157 & 71 \\
\hline & & & 160 & 69 \\
\hline & & \multirow{7}{*}{$\begin{array}{c}\text { Vibo Marina } \\
\text { (Calabria, Italy) }\end{array}$} & 134 & 56 \\
\hline & & & 135 & 44 \\
\hline & & & 136 & 45 \\
\hline & & & 140 & 55 \\
\hline & & & 143 & 51 \\
\hline & & & 144 & 54 \\
\hline & & & 151 & 60 \\
\hline \multirow{4}{*}{ Captive } & \multirow{4}{*}{ July } & \multirow{4}{*}{$\begin{array}{c}\text { Cartagena } \\
\text { (Spain) }\end{array}$} & 142 & 54 \\
\hline & & & 146 & 60 \\
\hline & & & 150 & 61 \\
\hline & & & 153 & 68 \\
\hline \multirow{14}{*}{ Wild } & \multirow{14}{*}{ May } & \multirow{8}{*}{$\begin{array}{c}\text { Island of San } \\
\text { Pietro (Sardinia, } \\
\text { Italy) }\end{array}$} & 133 & not available \\
\hline & & & 133 & not available \\
\hline & & & 135 & not available \\
\hline & & & 136 & not available \\
\hline & & & 145 & not available \\
\hline & & & 148 & not available \\
\hline & & & 152 & not available \\
\hline & & & 158 & not available \\
\hline & & \multirow{6}{*}{$\begin{array}{l}\text { Kenitra } \\
\text { (Morocco) }\end{array}$} & 200 & not available \\
\hline & & & 234 & not available \\
\hline & & & 235 & not available \\
\hline & & & 238 & not available \\
\hline & & & 250 & not available \\
\hline & & & 252 & not available \\
\hline \multirow{6}{*}{ Wild } & \multirow{6}{*}{ June } & \multirow{6}{*}{$\begin{array}{l}\text { Island of San } \\
\text { Pietro (Sardinia, } \\
\text { Italy) }\end{array}$} & 127 & not available \\
\hline & & & 148 & not available \\
\hline & & & 166 & not available \\
\hline & & & 170 & not available \\
\hline & & & 177 & not available \\
\hline & & & 216 & not available \\
\hline
\end{tabular}




\section{Figures}

Figure 1. Micrograph of testes of captive Atlantic bluefin tuna sampled at different phases of the spermatogenetic cycle. (a) In April, most fish were at an early spermatogenetic stage. (b) In May, fish were in late spermatogenetic stage, having all stages of spermatogenesis, as well as spermatozoa in the lumen of the seminiferous lobules. (c) In June, fish had residual sperm cysts in the germinal epithelium and the lumen of seminiferous lobules were filled with spermatozoa. (d) In July, fish were in a regressed ("spent") stage with residual spermatozoa in the lumen of the seminiferous lobules. Haematoxylin-eosin staining. Magnification bar in (a), (b), (c), (d) = $100 \mu \mathrm{m}$; in inset of $(a)=20 \mu \mathrm{m}$. Arrowhead: type $A_{\text {und }}$ spermatogonium; arrow: type $A_{\text {diff }}$ spermatogonial cyst; curved arrow: type B spermatogonial cyst; double arrow: spermatocyte cyst; dashed arrow: sperm cyst; sz: spermatozoa released in the lumen of seminiferous lobules.
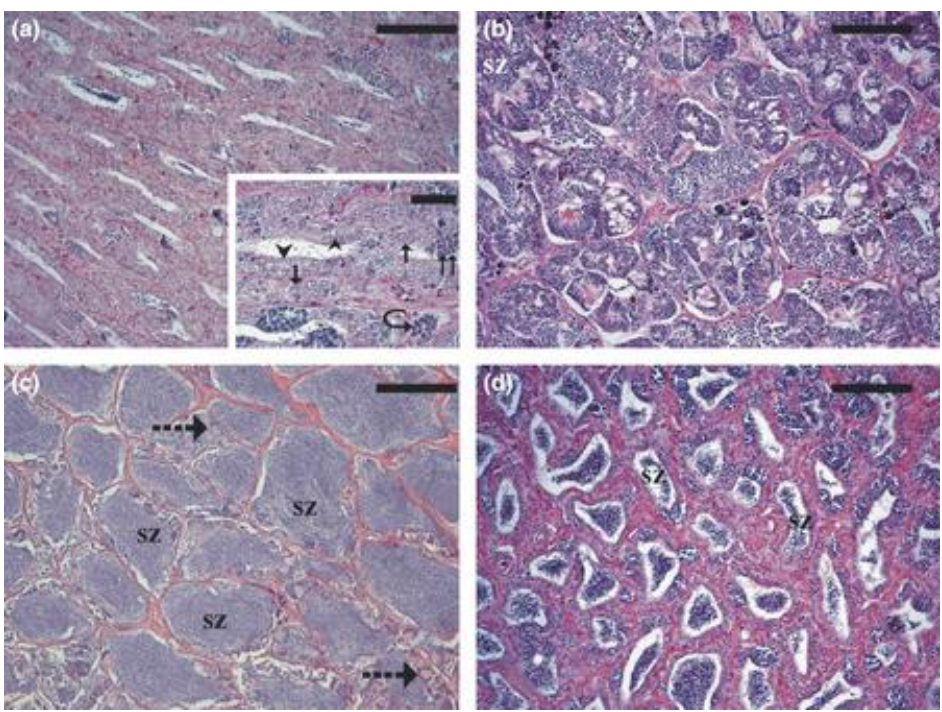
Figure 2. Micrograph of Atlantic bluefin tuna testes. (a) Testis section showing proliferating germ cells immunolabelled with antibodies against PCNA. Nuclei of proliferating cells are stained in brown. Magnification bar $=50 \mu \mathrm{m}$. Arrowhead: type $A_{\text {und }}$ spermatogonium; arrow: type $A_{\text {diff }}$ spermatogonial cyst; dashed arrow: type $B$ spermatogonial cysts; double arrow: spermatocyte cysts. (b) Testis section stained with the TUNEL method. Apoptotic cells and apoptotic bodies appear as dark blue dots. Magnification bar $=200 \mu \mathrm{m}$.
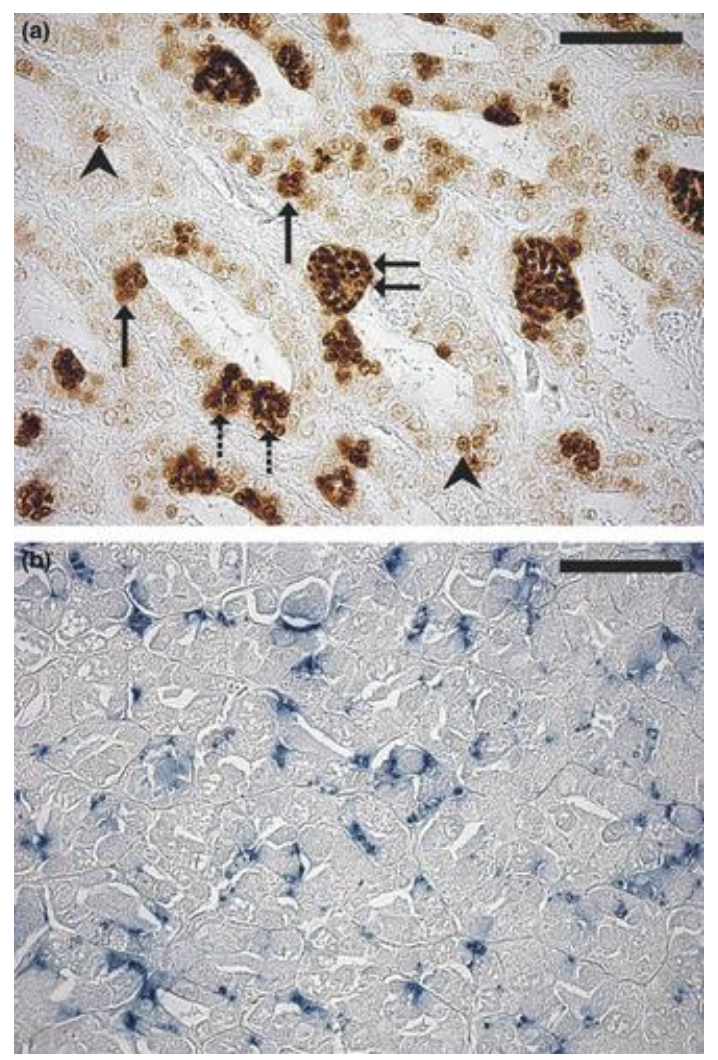
Fig. 3. Seminiferous lobule diameter (mean \pm SE) of Atlantic bluefin tuna reared in captivity (white bars) and collected from the wild (grey bars) during the spermatogenesis period (May) and the spawning period (June).

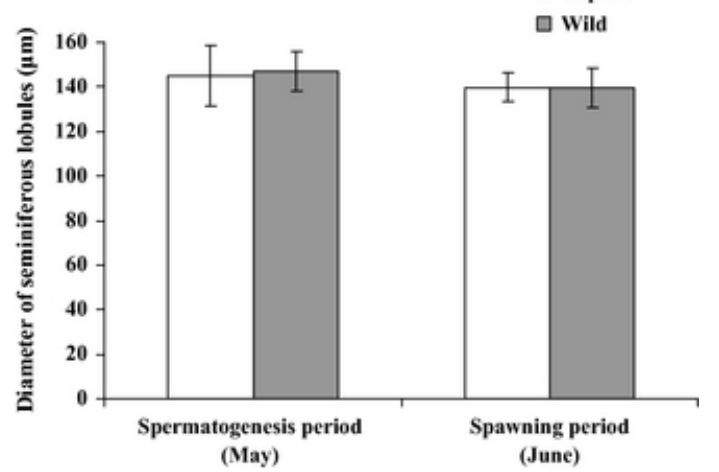

Figure 4. Changes in the mean $( \pm$ SE) anti PCNA positive germ cell density between spermatogenesis (May) and spawning (June) period in captive (white bars) and wild (grey bars) Atlantic bluefin tuna. (a) Anti PCNA positive $A_{\text {und }}$ spermatogonia. (b) Anti PCNA positive spermatogonial cysts (type $A_{\text {diff }}$ and type B spermatogonia). (c) Anti PCNA positive spermatocyte cysts. Asterisks indicate statistically significant differences between captive and wild means for each testicular condition ( ${ }^{*}: \mathrm{P}<0.05$; ** : $P<0.01)$; different letters indicate differences between subsequent testicular conditions in captive $(a \neq b)$ and wild $(x \neq y)$ samples, respectively.
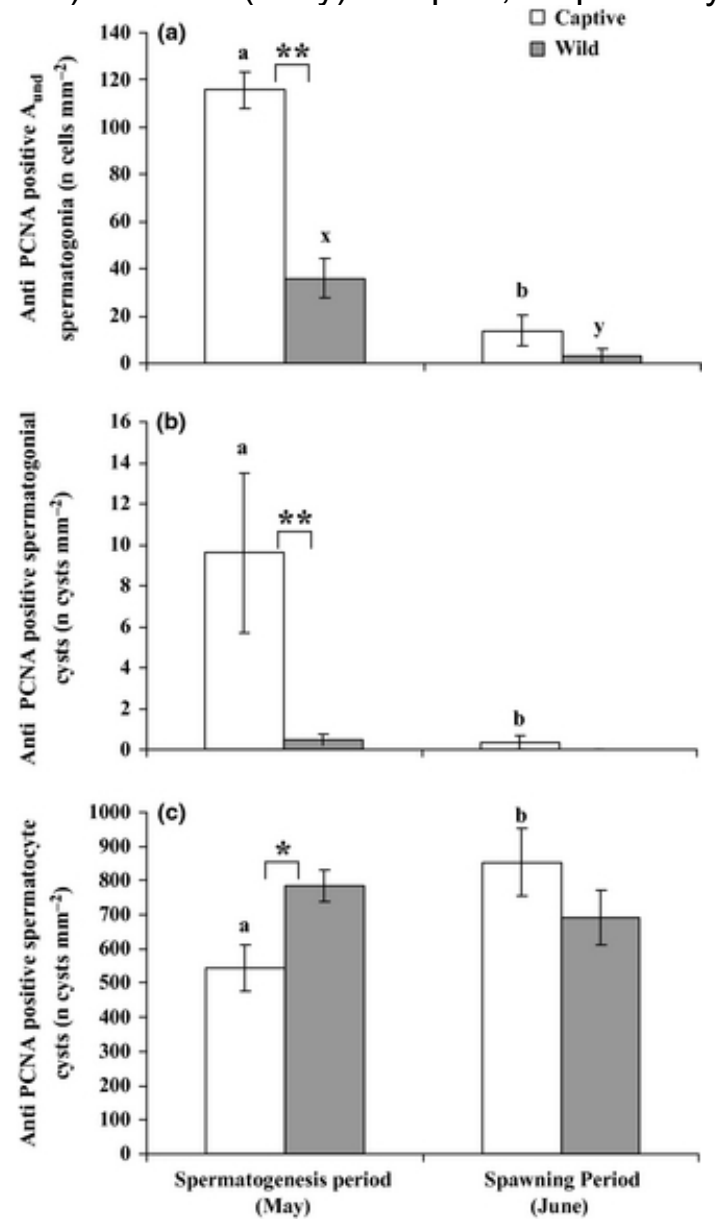
Figure 5. Changes in the mean ( \pm SE) surface occupied by apoptotic germ cells between spermatogenesis (May) and spawning (June) period in captive (white bars) and wild (grey bars) Atlantic bluefin tuna. Asterisks indicate statistically significant differences between captive and wild means for each testicular condition ( $\left.{ }^{*}: P<0.05\right)$; different letters indicate differences between subsequent testicular conditions in captive $(a \neq b)$ and wild $(x \neq y)$ samples, respectively.

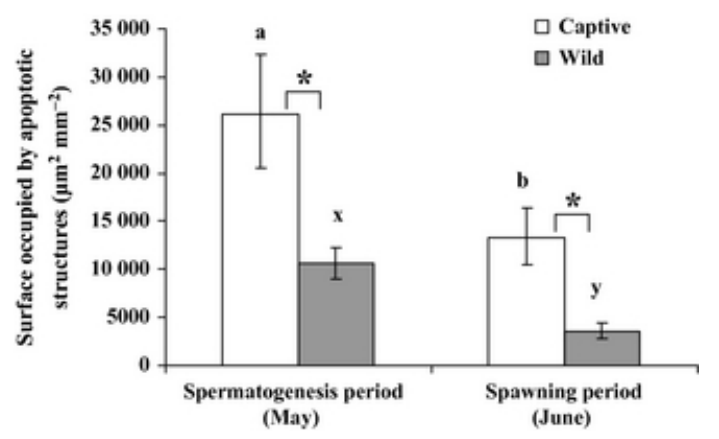

Figure 6. Changes in the percentage (number of fish $=5$; mean $\pm \mathrm{SE}$ ) of motile spermatozoa with time after activation in seawater containing $0.25 \%$ Pluronic F-68 (Sigma Aldrich).

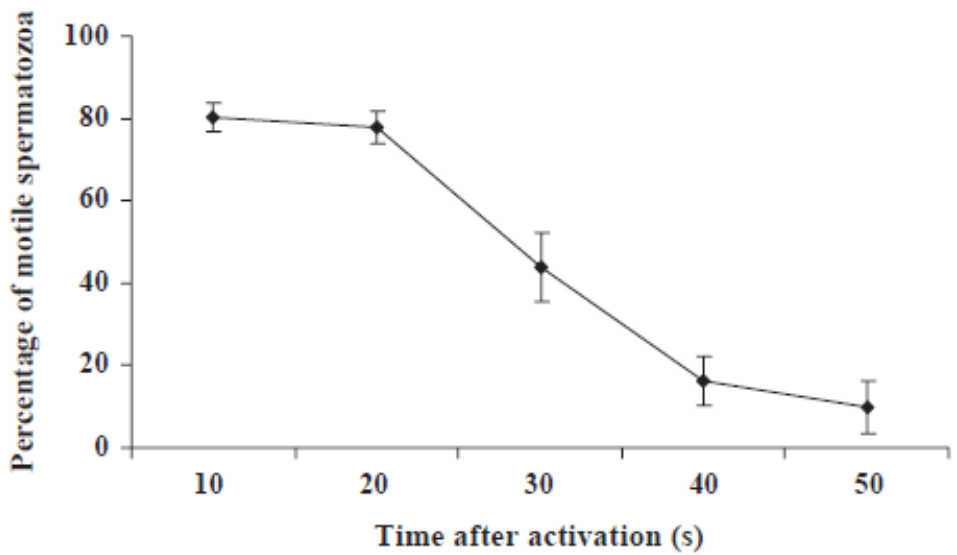


Figure 7. Average path velocity (mean \pm SE) of $25-35$ spermatozoa from each of 5 captive Atlantic bluefin tuna at $10 \mathrm{~s}$ intervals of time. The first assessment occurred at $10 \mathrm{~s}$ after activation with seawater containing $0.25 \%$ Pluronic F-68 (Sigma Aldrich) for each of the 5 males Different letters represent significantly different means (nested ANOVA; $P<0.05)$.
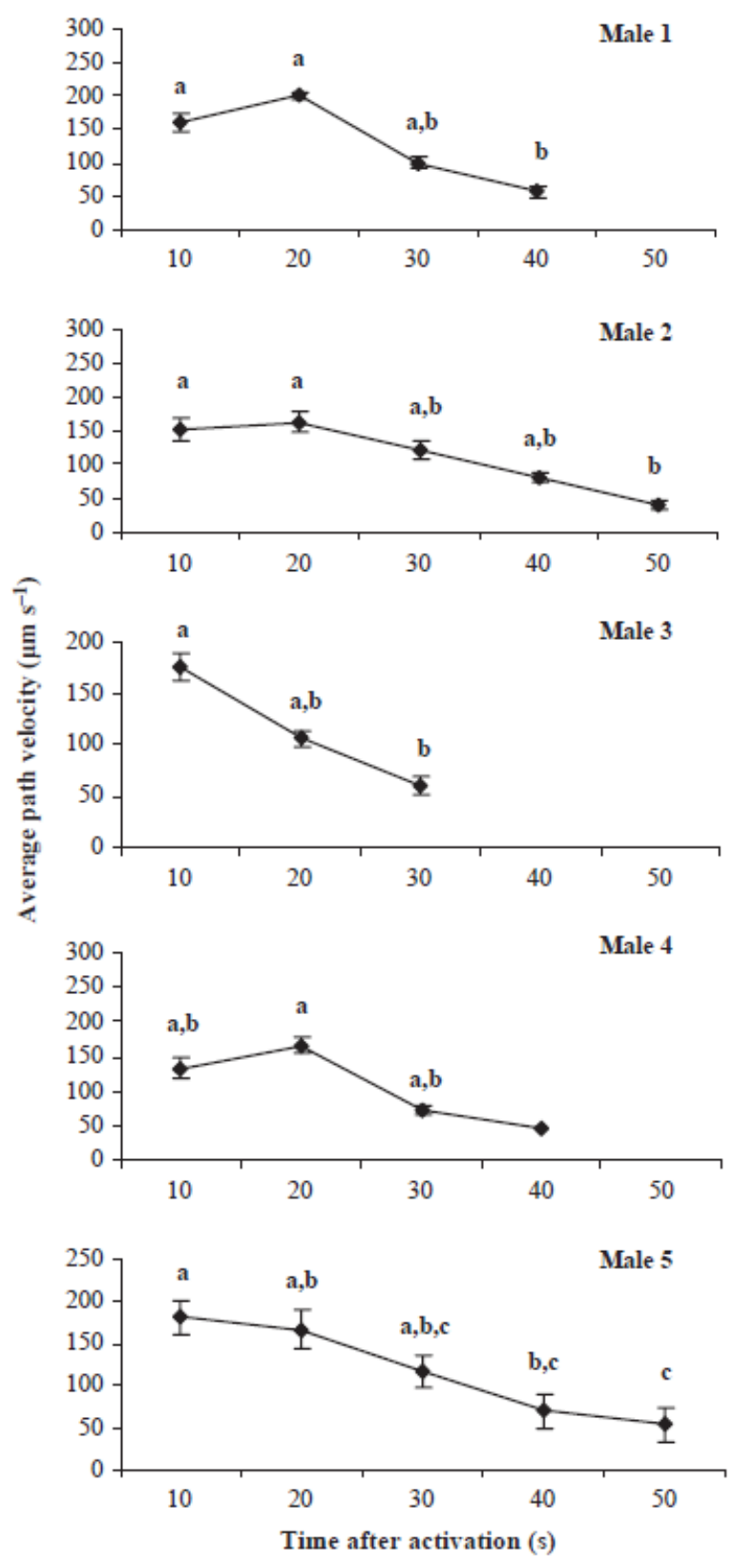
Figure 8. Atlantic bluefin tuna spermatozoa trajectories at different times after activation by seawater $(A)$ or $1 \mathrm{M}$ glucose calcium-free solution (B), generated by Computer Assisted Sperm Analysis (Image J, NIH, USA) using the same male semen. The trajectories represent the movements of spermatozoa for $1 \mathrm{~s}$, bars equal $100 \mu \mathrm{m}$. Mot: percentage of motile spermatozoa, $\mathrm{n}$ : total number of spermatozoa analyzed.
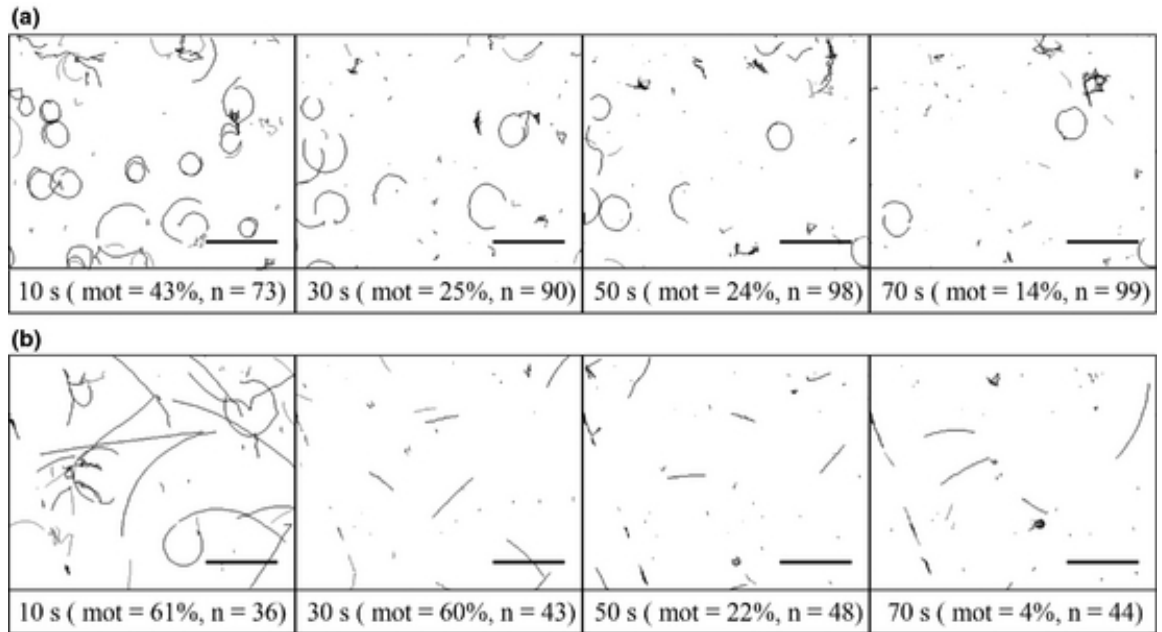